○藤多 健史,野呂 影勇 (早稲田大学 人間科学部)

田中 英夫（大阪府立大学 工学部）

\title{
A Fuzzy Aided System for Selection of School Chairs
}

OTakeshi FUJITA,Kageyu NORO(Dept. of Helth Science Waseda Univ.) Hideo TANAKA(Dept. of Industrial Engineering,Univ. of Osaka Prefecture)

\section{1.はじめに}

小学生の椅子選びは学校保健衛生上重要な問 題である。しかし、現実問題として現場で椅子 選びを適切に行うことは困難なことが多い。な ぜなら、教員一人あたりの受持ち児童数が多い 上に、椅子に関する知識を持つ教員が少ないか らである。そこで椅子に関する知識や経験の乏 しい教員が敏速かつ簡便に適切な椅子選びを行 えるよう、現場で永年、小学生の椅子に関する 研究を行ってきた養護教諭の経験と知識を取り 込んだ意志決定支援システムを構筑することで 解決策を試みた。そのためには、比較的人間に 近い推論・判断が期待できるファジィ推論を応 用することが適当であると判断し、本支援ファ ジィシステムのプロトタイプを開発した。その 概略と現状について報告する。

\section{2.ファジィ推詥について}

ファジィ推論は次の 2 種類に大別できる。
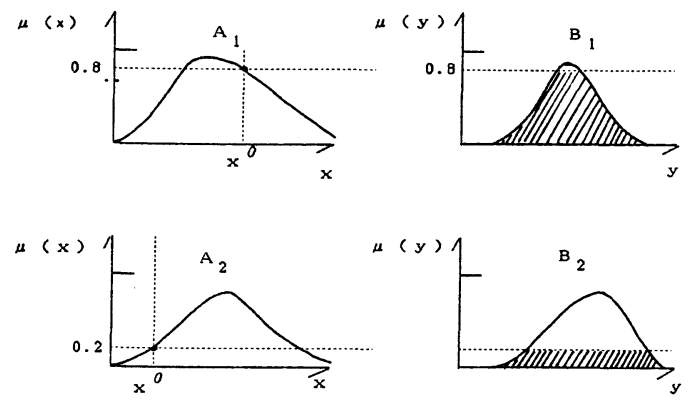

図 1 : ファジィプロダクション ルールの推論
1) ファジィプロダクションルールを使用

2) ファジィ関係を使用

本システムでは前者を利用している都合、これ について触れる。

今、エキスパートによるファジィプロダクショ ンルールが次のように得られたとする。

if $A 1$ then $B 1$

if $A 2$ then $B 2$

ここでA1，B 1, A 2, B 2 はファジィ集合で与え られ、現在の入力状態がX0で与えられたとき結 論 $\mathrm{Y} 0$ をどの様にして出力するかを図 1 に示す。 これには、Yagerによる頭切り法（min合成）を 使用している。本システムすこれに準じている。 次に頭切りの結果 B 1, B 2をmax合成を用いて統 合し結論を得る。しかし、最終的には 2 值的な 確定値Y0を与えなければならない。このために は図 2 のように結論の可能性分布の重心を採用 することが多い。本システムす重心法を採用し ている。

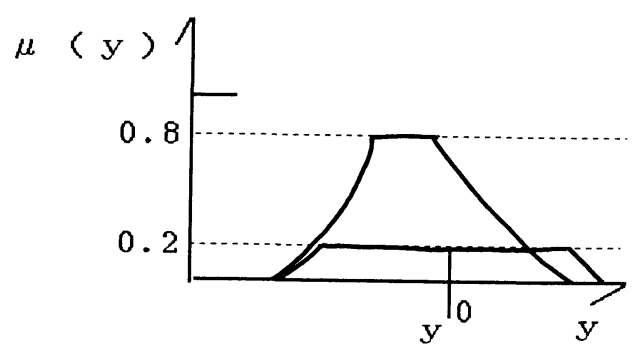

図 2: ファジィ推論結果の確定值化 


\section{3. システム構成}

システムは通常の意志決定支援システムと同 様に推論機構部、ワーキングメモリ、知識ベー スを基本に構成されている。ただし、推論機構 部、ヒューマンインターフェイおよび知識ベー スにファジィ理論が応用されている。

3. 1 知識ベース

”大きい””長い”など曖昧な日常言語で表 現されているプロダクションルールをファジィ 集合として直接、知識べースに取り込んでいる。 プロダクションルールは各学年、各体格イメー ジによって木構造を成している。

\section{2 ヒューマンインターフェイス}

簡便かつ敏速な方法開発が第一目的である。 ゆえに計測などの面倒さを克服するため本シス テムへの入力は、児童の学年、体格イメージ、 ならびに各身体箇所に関するイメージをマウス によって数直線上にプロットするだけである。 入力画面を図 3 に示す。

\section{3 想定するコーザー}

本システムにはイメージを入力するため小学 生の身体を見慣れている者でなければ適正な運 用が出来ない恐れがある。よってユーザとして は小学校の教諭に限定している。

\section{4 推論機構部}

推論は基本的には第 2 項で述べたようにmin$\max$ 合成を行い、結論の可能性分布の重心点を確 定值として結論とする。推論過程は運用者にグ ラフとして示すことが出来る。この内容明示性 あファジィ推論の特徴の一つである。グラフの 一例を図 4 に示す。

\section{4. 今後の課題}

ファジィ集合のメンバーシップ関数は、よい 意味です悪い意味です、その主観性に特徵を持 つ。従って、システムにニューラルネットを応 用した学習機能を持たせることは必須の課題で ある。

\section{5.まとめ}

本研究において小学生の椅子選びの簡便法開 発の一つの試案としてファジィ推論を応用した 意志決定支援システムを提示した。さらに現場 でのラップトップタイプパソコンによる運用実 験を継続的に行い実用化を目指したい。

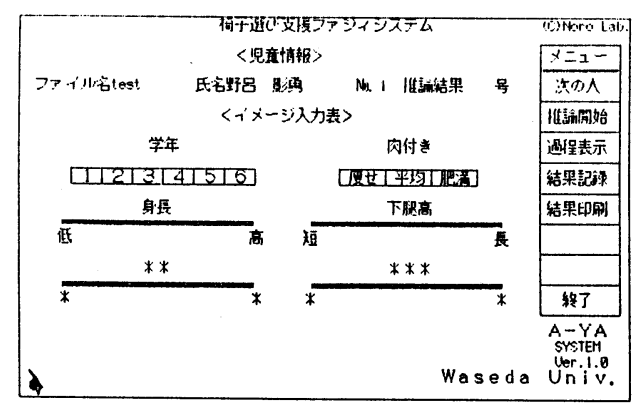

図 3：支援ファジィシステムの入力画面

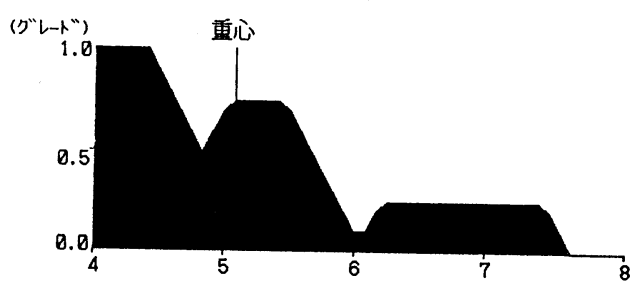

図 4 : 推論過程表示画面の一例

\section{6. 謝辞}

(重心点探索結果)

本システムに推論ルールを提供して下さった 北九州市小倉南北区養護教諭部会の先生方なら びに実験に協力してくれた北九州市立城野小学 校、貴船小学校の先生と児童の皆さんに謝意を 表します。

\section{参考文献}

(1)水野雅晴: ファジィ理論とその応用、サイエ ンス社 (1988)

(2)田崎栄一郎 : ”ファジィ・エキスパートシス テム”、数理科学 (1987年2月号)

(3)田中英夫 : 人間に近づくコンピューター、C \&Cスクール (1989) 